\title{
Cornsilk Fly, Euxesta stigmatias Loew (Insecta: Diptera: Otitidae) ${ }^{1}$
}

John L. Capinera ${ }^{2}$

\section{Distribution}

The cornsilk fly, Euxesta stigmatias Loew, is found in tropical and subtropical areas of the western hemisphere. It occurs throughout the Caribbean Islands, Mexico, Central and South America south to Bolivia and Paraguay, and in Florida. Historically it has been a pest in the United States only in southernmost Florida, Puerto Rico, and the Virgin Islands. However, in recent years cornsilk fly has become a serious pest in south-central Florida, and there are sporadic reports of its occurrence from a few other states.

\section{Life Cycle and Description}

The phenology of these flies is poorly documented, but they seem to be present throughout the year in southern Florida. The life cycle requires only about 30 days so it is apparent that several generations occur annually. Overwintering potential is unknown.

\section{Eggs}

Eggs are deposited principally at the tip of the ear, on or near the silk at the point of emergence from the ear. Young ears are most preferred; decaying ears are avoided. In the absence of ears, eggs may be deposited at the base of leaves or elsewhere, but survival rates are much lower than when they are deposited in ears. Eggs measure about $0.85 \mathrm{~mm}$ in length and $0.16 \mathrm{~mm}$ in width. They are white in color and cylindrical in shape, with ends that taper to a broadly rounded point. There are reports of eggs being laid singly, in a row and fastened end to end, or in clusters of up to 40 eggs. Females may cluster on corn ears and deposit hundreds of eggs in individual ears. Duration of the egg stage is two to four days.

\section{Larvae}

Larvae (Figure 1) are elongate and cylindrical in shape, with a blunt, broadly rounded posterior that tapers to a pointed head which is equipped with a pair of mouth hooks. Mature larvae measure about 5.4 $\mathrm{mm}$ in length. Larvae are whitish in color, and the ventral surface bears ridges and coarse spines.

Duration of the larval stage averages about 7.5 days.

1. This document is EENY-224, one of a series of Featured Creatures from the Entomology and Nematology Department, Florida Cooperative Extension Service, Institute of Food and Agricultural Sciences, University of Florida. Published: August 2001. This document is also available on Featured Creatures Website at http://creatures.ifas.ufl.edu. Please visit the EDIS Website at http://edis.ifas.ufl.edu. Additional information on these organisms, including many color photographs, is available at the Entomology and Nematology Department website at http://entnemdept.ifas.ufl.edu/.

2. John L. Capinera, chairman/professor, Entomology and Nematology Department, Institute of Food and Agricultural Sciences, University of Florida, Gainesville, FL

The Institute of Food and Agricultural Sciences (IFAS) is an Equal Employment Opportunity - Affirmative Action Employer authorized to provide research, educational information and other services only to individuals and institutions that function without regard to race, creed, color, religion, age, disability, sex, sexual orientation, marital status, national origin, political opinions or affiliations. For information on obtaining other extension publications, contact your county Cooperative Extension Service office. Florida Cooperative Extension Service / Institute of Food and Agricultural Sciences / University of Florida / Larry R. Arrington, Interim Dean 


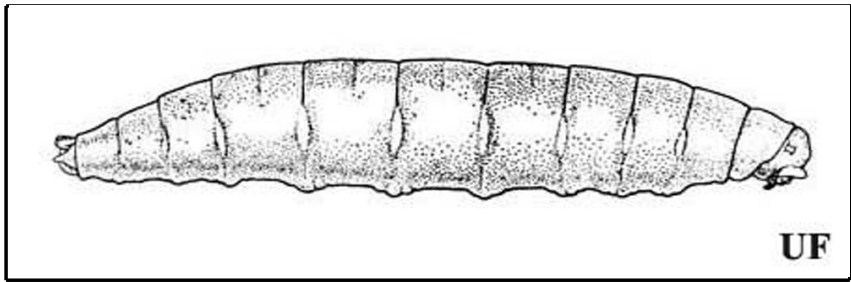

Figure 1. Larva of the cornsilk fly, Euxesta stigmatias Loew. Credits: University of Florida

\section{Pupae}

Pupation commonly occurs on the corn silks inside the corn ears, but sometimes in the soil. The puparia are elongate and cylindrical, with the anterior end tapered to a blunt point and the body slightly flattened. They measure about $3.9 \mathrm{~mm}$ in length and $1.4 \mathrm{~mm}$ in width. Puparia are yellowish initially, becoming reddish brown after a few hours and then dark brown at maturity. Mean duration of the pupal stage is about 7.5 days.

\section{Adults}

Adult flies (Figure 2) are metallic green or black in color, with reddish eyes, and wings banded with black. Males measure about $3.8 \mathrm{~mm}$ in length, females about $4.2 \mathrm{~mm}$. Adults feed on nectar, plant sap and glandular exudates, and also drink from dew and rain droplets. They tend to move their wings continuously, even while alighted. Adults frequent corn plant tassels and ears more than other plant parts. Mating occurs principally at dusk and dawn.

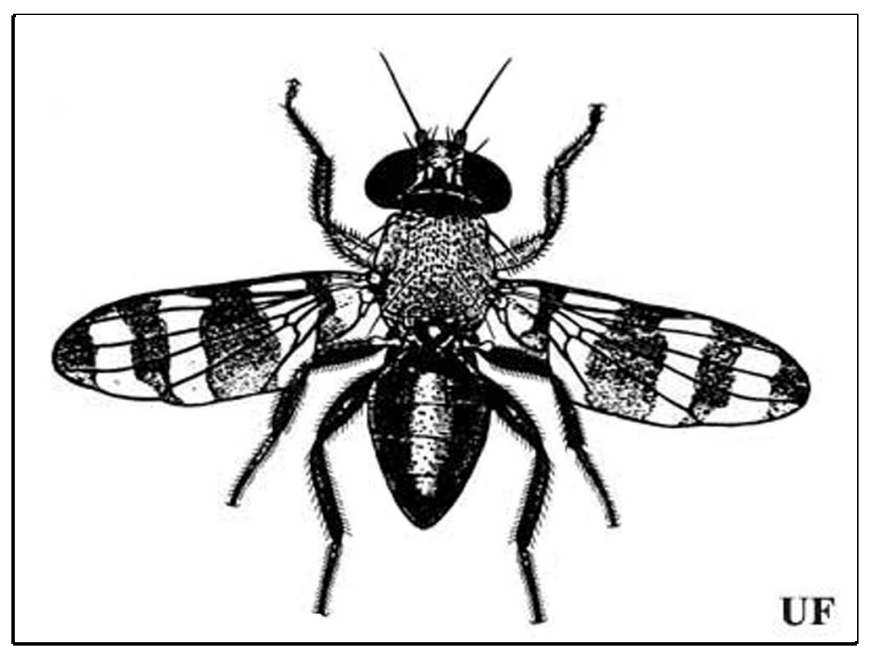

Figure 2. Adult cornsilk fly, Euxesta stigmatias Loew. Credits: University of Florida

Biology is described by App (1938), Seal and Jansson $(1989,1993)$, and Seal et al. (1995, 1996).

\section{Host Plants}

Larvae and adults feed on a wide variety of plants, including such vegetables as sweet corn, potato, and tomato; such field crops as field corn, sorghum, and sugarcane; and such fruit crops as atemoya, banana, guava, and orange. However, sweet corn and field corn are highly preferred, and the only crops to be seriously damaged.

\section{Damage}

Damage is caused by the larval stage. Larvae feed on the silks, but the principal injury is to the developing kernels on the ear, where they often hollow out the kernels. Larvae may be found feeding along the entire length of the ear, or mostly at the tip. Larvae also bore into the cob, resulting in ear deformity, and introduce fungi beneath the ear sheath. Yield reductions of $95 \%$ are reported, with peak levels of damage early in the season (Seal and Jansson 1989, Seal et al. 1996). Significant damage occurs even when insecticides are applied.

\section{Natural Enemies}

Little is known concerning natural enemies. Eggs are consumed by earwigs (Dermaptera), mites (Acarina), and minute pirate bugs (Hemiptera: Anthocoridae) (Figure 3).

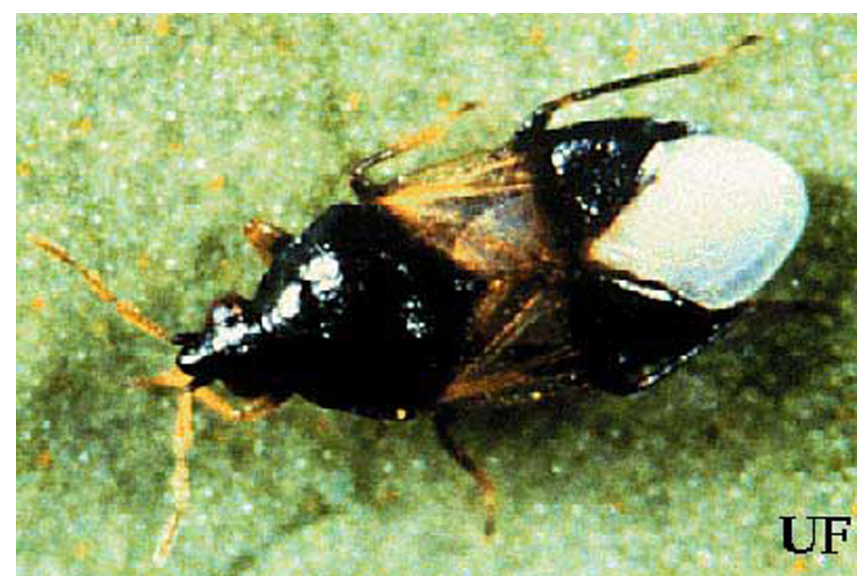

Figure 3. A minute pirate bug (Hemiptera: Anthocoridae); a predator of the cornsilk fly, Euxesta stigmatias Loew. Credits: University of Florida 


\section{Management}

Sampling and management tactics are poorly developed. Sampling should commence before tasselling is initiated. Adults can be detected in the late afternoon and early evening when they rest on the plants and mate on the tassel. During silking, silks should be checked for the presence of eggs. Growers in affected areas rely on frequent insecticide applications to maintain a toxic residue on the rapidly developing corn silk. Alternatives to insecticides are few. Covering the tassel and ear with a bag can reduce the number of larvae found in ears, but because the silk must remain uncovered until the ear is pollinated, some oviposition is likely to occur on the young silks.

For more management information, see:

Insect Management Guide for Sweet Corn

(http://edis.ifas.ufl.edu/IG158)

Insect Management Guide for Field Corn

(http://edis.ifas.ufl.edu/IG060)

\section{Selected References}

App BA. 1938. Euxesta stigmatias Loew, an otitid fly infesting ear corn in Puerto Rico. Journal of Agriculture of the University of Puerto Rico 23:181-187.

Capinera JL. Handbook of Vegetable Pests. Academic Press, San Diego. 729 pp.

Nuessly G. et al. (27 October 1999). Florida Corn Insect Identification Guide. UF/IFAS. http://fciig.ifas.ufl.edu/frcsilk.htm (27 July 2001).

Seal DR, Jansson RK. 1989. Biology and management of corn-silk fly, Euxesta stigmatis Loew (Diptera: Otitidae), on sweet corn in southern Florida. Proceedings of the Florida State Horticultural Society 102:370- 373.

Seal DR, Jansson RK. 1993. Oviposition and development of Euxesta stigmatis (Diptera: Otitidae). Environmental Entomology 22:88-92.
Seal DR, Jansson RK, Bondari K. 1995. Bionomics of Euxesta stigmatis (Diptera: Otitidae) on sweet corn. Environmental Entomology 24:917-922.

Seal DR, Jansson RK, Bondari K. 1996. Abundance and reproduction of Euxesta stigmatis (Diptera: Otitidae) on sweet corn in different environmental conditions. Florida Entomologist 79:413-422. 